\title{
Structural analysis of the giant linear plasmid SCP1 in various Streptomyces coelicolor strains
}

\author{
Haruyasu Kinashi, ${ }^{1 *}$ Miyuki Murayama, ${ }^{2}$ Hitoshi Matsushita ${ }^{1}$ and Osamu Nimi ${ }^{1}$ \\ ${ }^{1}$ Department of Fermentation Technology, Hiroshima University, Higashi-Hiroshima 724, Japan \\ ${ }^{2}$ Mitsubishi Kasei Institute of Life Sciences, Minamiooya, Machida, Tokyo 194, Japan
}

Received 6 November 1992; revised 25 December 1992; accepted 18 January 1993)

\begin{abstract}
The methylenomycin biosynthetic gene cluster was previously shown to be present on the $\mathbf{3 5 0} \mathrm{kb}$ giant linear plasmid SCP1. The structures of SCP1 in various Streptomyces coelicolor A3(2) strains were analysed by pulsed field gel electrophoresis (PFGE). S. coelicolor A3(2) strains 1147, M138 and M146, previously genetically characterized as SCP1 ${ }^{+}$, contained the free form of SCP1. S. coelicolor 1984 and 2106 , earlier characterized as $\mathrm{SCP1} 1^{\prime}-\operatorname{cys} B$ and a stable cys $D$ donor respectively, were found to contain very large linear plasmids, $550 \mathrm{~kb}$ and $1700 \mathrm{~kb}$ in size. Strain JCM4979, another SCP1 ${ }^{+}$derivative of A3(2), had a series of SCP1-related linear plasmids of 390-630 kb. The integrated states of SCP1 in S. coelicolor SCP1-NF strains, an NF-like strain and a stable $p a b A$ donor were confirmed by PFGE, which revealed a lack of the intact SCP1 termini. In addition, a $70 \mathrm{~kb}$ linear plasmid was found in Streptomyces violaceoruber SANK95570, another methylenomycin producer. However, the plasmid was shown by hybridization to a methylenomycin resistance gene not to carry the methylenomycin gene cluster of this strain.
\end{abstract}

\section{Introduction}

The plasmid SCP1 was first defined genetically by its control of various fertility states of the host strain Streptomyces coelicolor A3(2) (Vivian, 1971; Vivian \& Hopwood, 1970, 1973) and its control of production of, and resistance to, the antibiotic methylenomycin (Kirby et al., 1975; Kirby \& Hopwood, 1977). It is a giant $(350 \mathrm{~kb})$ linear double stranded plasmid (Kinashi et al., 1987), and extensive physical characterization of its free form in S. coelicolor M138 $\left(\mathrm{SCP}^{+}\right)$has revealed that it has unusually long terminal inverted repeats (TIRs) on both ends, that it contains an insertion sequence IS466 at the inside end of the right TIR (TIR-R), and that the 5' ends are attached to a protein (Kinashi \& ShimajiMurayama, 1991). The lengths of the right and left TIRs (TIR-R and -L) were determined to be about $80 \mathrm{~kb}$ by cloning and sequencing of both end-points (Kinashi et al., 1991). A physical map of the 15 EcoRV fragments of SCP1 was constructed by digestion, hybridization, and cloning (Fig. 1). The methylenomycin resistance ( $\mathrm{mmr}$ ) gene (Bibb et al., 1980) hybridized to the EcoRV-C fragment, indicating the presence of the methylenomycin

*Author for correspondence. Tel. 81824247767 ; fax 8182422 7191. biosynthetic (mmy) gene cluster (Chater \& Bruton, 1985) on this fragment (Fig. 1).

SCP1 has the following unique properties. (1) It codes for several spore-associated proteins which might be involved in spore formation of S. coelicolor (McCormick et al., 1991), although they are not essential for this process since $\mathrm{SCP} 1^{-}$strains sporulate apparently normally. (2) It carries the entire biosynthetic gene cluster for the antibiotic methylenomycin (Chater \& Bruton, 1985; Kinashi et al., 1987). (3) It has been shown by genetic studies to be present in various forms in $S$. coelicolor A3(2) strains, namely, (i) as an autonomously replicating plasmid $\left(\mathrm{SCP}^{+}\right)$, (ii) as an autonomously replicating plasmid containing a chromosomal fragment (SCP1'-cys B and SCP1'-argA uraB; Hopwood $\&$ Wright, 1973, 1976a), and (iii) integrated into the chromosome (SCP1-NF strains and various other stable donor strains; Vivian \& Hopwood, 1970, 1973; Hopwood \& Wright, 1976b).

Here we focus on the last of these properties. In $S$. coelicolor SCP1-NF strains, SCP1 is integrated in the chromosome at the 9 o'clock position of the linkage map (Hopwood et al., 1973). Analysis of the two junctions between the SCP1 DNA and the chromosomal DNA in this strain revealed that the left junction (JL) had an almost intact left terminus of SCP1, while the right 


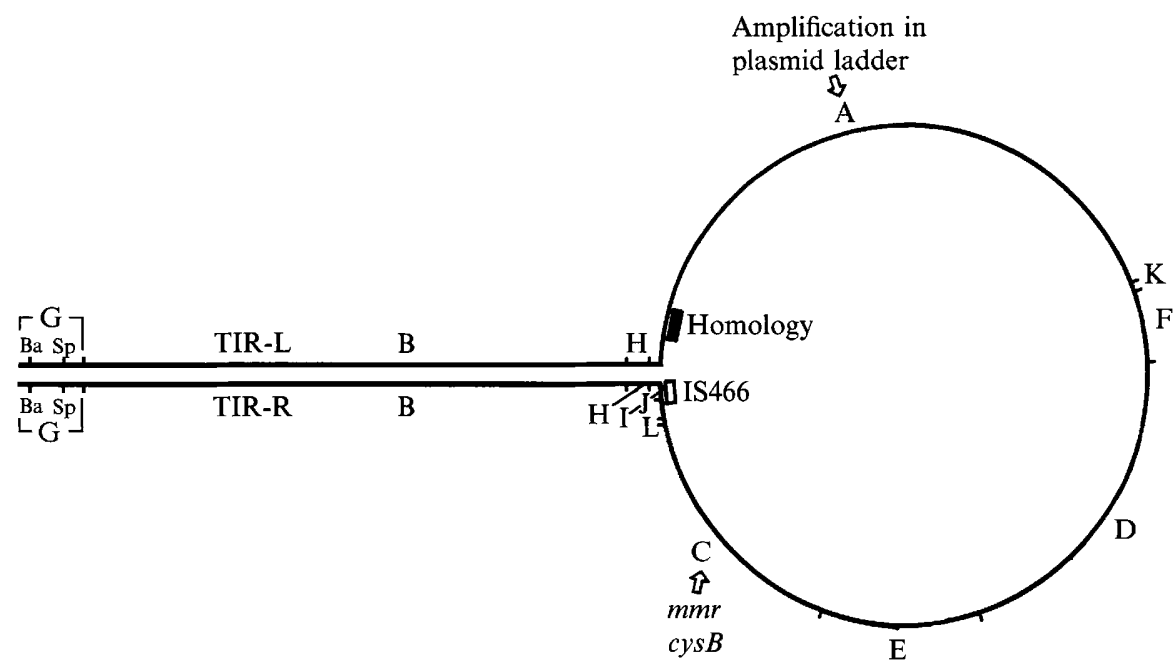

Fig. 1. A physical map of the $15 E c o$ RV fragments of SCP1 drawn as a racket-frame structure (Kinashi \& Shimaji-Murayama, 1991). In addition to $E c o$ RV fragments A-L, the terminal BamHI (Ba) and SpeI (Sp) sites discussed in the text are also shown. The 'handle' part marked by TIR-L and TIR-R contains the unusually long (about $80 \mathrm{~kb}$ ) terminal inverted repeats. The white box indicates IS466 (Kendall \& Cullum, 1986); the black box, the homologous sequence to SCP2. Plasmid pIJ601, which contains the mmr gene, hybridized to fragment $E c o \mathrm{RV}-\mathrm{C}$. The cysB locus is integrated into fragment $E c o \mathrm{RV}-\mathrm{C}$ in the 1984 strain and the amplification is present on fragment EcoRV-A in the plasmid ladder of JCM4979.

junction (JR) was composed of IS466, with complete deletion of TIR-R. From these results, we proposed a model for generation of the NF strain (Hanafusa \& Kinashi, 1992; Kinashi et al., 1992), which is in accordance with the racket-frame structure of SCP1 (Sakaguchi, 1990).

Streptomycetes exhibit extreme genome fluidity; for example, deletion, amplification, and site-specific integration or excision (Chater et al., 1988; Huetter et al., 1988). However, the molecular reasons for this characteristic are still relatively poorly understood. Molecular analysis of the dynamic structural changes of SCP1 in various $S$. coelicolor strains is expected to assist in understanding the reasons underlying the genome fluidity of streptomycetes. As a step toward this goal, we describe here the structural analysis of various forms of SCP1 in several derivatives of $S$. coelicolor A3(2). A preliminary report of part of this work has already appeared (Kinashi, 1989).

\section{Methods}

Bacterial strains and plasmids. Streptomyces strains used are shown in Table 1. All of the $S$. coelicolor A3(2) strains except JCM4979 were from the John Innes Institute Collection. Strain JCM4979 was obtained from the Japan Collection of Microorganisms (JCM), Saitama, Japan, under the name Streptomyces violaceoruber. This strain is a subculture by G. Sermonti from an A3(2) strain obtained from D. A. Hopwood in 1960 (D. A. Hopwood, personal communication) and therefore is called $S$. coelicolor JCM4979 in this paper. S. violaceoruber SANK95570, another methylenomycin producer (Haneishi et al., 1974), was provided by T. Haneishi, Sankyo. pIJ601, containing the methylenomycin resistance gene ( $m m r$ ) (Aguilar \& Hopwood, 1982), pSCP201, containing the $4.1 \mathrm{~kb}$ terminal SpeI fragment of SCP1 (Kinashi et al., 1991), and SCP2 (Bibb \& Hopwood, 1981) from $S$. coelicolor 1098 were used as probes for hybridization.

DNA isolation and manipulation. Streptomyces strains were cultivated in YEME medium (Hopwood et al., 1985), collected by centrifugation, washed with $10 \cdot 3 \%(\mathrm{w} / \mathrm{v})$ sucrose and stored at $-40^{\circ} \mathrm{C}$. Total DNA samples for PFGE analysis were prepared in low melting point agarose as described by Kinashi \& Shimaji-Murayama (1991). Total DNAs were also prepared in solution by a neutral method (Tanaka et al., 1977). Giant linear plasmids were separated by orthogonal field alternation gel electrophoresis (OFAGE) (Carle \& Olson, 1987) or contour-clamped homogeneous electric fields (CHEF) (Chu et al., 1986) and were electroeluted from gels if necessary. Digestion of giant linear plasmids in low melting point agarose was as described by Kinashi \& Shimaji-Murayama (1991).

Southern hybridization. pIJ601 and pSCP201 were isolated from Escherichia coli strains by an alkaline lysis method (Sambrook et al., 1989). SCP2 was isolated from $S$. coelicolor 1098 by a neutral lysis method (Tanaka et al., 1977) followed by caesium chloride gradient ultracentrifugation. For use as hybridization probes, pIJ601 and SCP2 were labelled with $\left[{ }^{32} \mathrm{P}\right] \mathrm{dCTP}$ (Amersham) and pSCP201 was labelled with digoxigenin-labelled dUTP (Boehringer). After agarose gel electrophoresis, DNA fragments were transferred to nitrocellulose or Nytran-N membrane filters (Schleicher and Schuell) by the capillary method. Southern hybridization was carried out as described by Hopwood et al. (1985b) or according to the manufacturer's protocol (Boehringer).

\section{Results}

\section{Analysis of $S C P 1^{+}$and $S C P 1^{\prime}$ strains}

The structures of the giant linear plasmid SCP1 in various $S$. coelicolor A3(2) strains were first analysed by 
OFAGE and Southern hybridization, using pIJ601 and SCP2, respectively, as probes (Fig. 2). The sizes of giant linear plasmids detected in this experiment, which included some strains studied previously (Kinashi, 1989), are summarized in Table 1.

S. coelicolor 1147, the John Innes Institute A3(2) wildtype $\mathrm{SCP} 1^{+} \mathrm{SCP} 2^{+}$culture, contained the linear SCP1 as well as the ccc SCP2 (data not shown in Fig. 2), while the SCP $1^{+} \mathrm{SCP}^{-}$strains M138 and M146 showed only SCP1. S. coelicolor 1984 was characterized genetically as an SCP1'-cysB strain (Hopwood \& Wright, 1976a), while 2106 was described as a stable 'unidirectional' cysD donor (Hopwood \& Wright, 1976b). OFAGE analysis of these strains revealed the presence of giant linear plasmids of 550 (presumed to be SCP1'-cysB) and $1700 \mathrm{~kb}$, respectively. As shown in Fig. 2(a-d), pIJ601 containing the $m m r$ gene hybridized to both plasmids.

Plasmid SCP1'-cysB in the 1984 strain was studied by digesting with EcoRV in agarose gels. CHEF analysis revealed that all the large EcoRV fragments of SCP1 were present in the digest of SCP1'-cys $B$, except for the $40 \mathrm{~kb}$ EcoRV-C, which changed to a $140 \mathrm{~kb}$ fragment, $E c o$ RV-C' (Fig. 3, lane 3). This suggests that a chromosomal fragment of about $100 \mathrm{~kb}$, including the cys $B$ locus, might have been inserted into EcoRV-C of $\mathrm{SCP} 1$. The extremely large linear plasmid $(1700 \mathrm{~kb})$ of strain 2106 has not yet been analysed because of its difficulty of isolation.

A plasmid ladder (390-630 kb) with a size difference of about $40 \mathrm{~kb}$ between the different molecules was found in strain JCM4979 (Fig. 2). This strain is a sub-culture of the A3(2) strain, which was added to the JCM collection through G. Sermonti as S. violaceoruber A3(2). Therefore, this strain was originally the same as the 1147 strain and was expected to be $\mathrm{SCP} 1^{+} \mathrm{SCP} 2^{+}$. However, the plasmid patterns of the two strains are now different. To test the possibility of SCP2 having integrated into SCP1, Southern blot analysis was performed with pIJ601 and $\mathrm{SCP} 2$ as probes. Both probes hybridized to the plasmid ladder in JCM4979, while SCP2 did not hybridize to SCP1 in the M138 strain, indicating integration of SCP2 into SCP1 in JCM4979 (Fig. $2 a, b, e, f$ ).

The three smallest bands, of 390,430 and $470 \mathrm{~kb}$, respectively, were separated from the plasmid ladder by CHEF electrophoresis, and digested in situ with EcoRV. CHEF analysis indicated that all three plasmids had the same EcoRV restriction patterns except that the sizes of the Eco RV-A' fragments were 150,190 , and $230 \mathrm{~kb}$, respectively, compared with $80 \mathrm{~kb}$ for $E c o \mathrm{RV}-\mathrm{A}$ of SCP1 (Fig. 3, lanes 4-7). At first, we speculated that these plasmids might have two, three and four integrated SCP2 molecules, respectively (Kinashi, 1989). However, the following hybridization studies revealed that an intact SCP2 molecule was not present in these plasmids.
DNA from a mixture of components of the plasmid ladder was digested with five restriction endonucleases, separated by conventional agarose gel electrophoresis and analysed by Southern hybridization using SCP2 as a probe. A precise physical and functional map of SCP2*, a variant of SCP2 with no detectable physical difference from SCP2, was made by Lydiate et al. (1985) and is reproduced in Fig. 4. Most of the SCP2 fragments have their counterparts in the plasmid DNA digest in Fig. 5. However, the $5.0 \mathrm{~kb} \mathrm{XbaI}, 13.2 \mathrm{~kb} \mathrm{KpnI}$ and $8.9 \mathrm{~kb}$ Bam $\mathrm{HI}$ fragments of SCP2 expected from the map were not observed in the plasmid DNA digest. All of these fragments are present on the upper right of the circular map of SCP2. This implies that the integrated SCP2 molecule in the plasmid ladder has lost its upper right region. However, bands corresponding to the $9.3 \mathrm{~kb} S p h \mathrm{I}$ and $9 \cdot 1 \mathrm{~kb} P s t \mathrm{I}$ fragments from the same region of SCP2 were seen in the plasmid DNA digest, but the sizes of these fragments might coincide with those of SCP2 by chance.

The two junctions between the SCP1 and SCP2 DNA in the plasmid ladder were cloned and sequenced (Kinashi, 1989). The result indicated that SCP2 was not intact in the plasmid ladder but had suffered a $4.0 \mathrm{~kb}$ deletion from $4.0 \mathrm{~kb}$ to $8.0 \mathrm{~kb}$ from the EcoRI site as shown in Fig. 4. It is especially interesting that the deleted region corresponds to the stability region of SCP2.

As expected, no plasmid was detected in the $\mathrm{SCP}^{-}{ }^{-\mathrm{SCP}} 2^{-}$strains, S. coelicolor $\mathrm{M} 124$ and M130 (Fig. $2 a, b$ ), and only SCP2 was detected in $\mathrm{SCP}^{-} \mathrm{SCP}^{+}$ S. coelicolor 1098 (Fig. 2e,f).

\section{Analysis of strains with an integrated SCPI plasmid}

Three NF strains, S. coelicolor 2612, A317 and A332, a stable pabA donor strain A608, and an NF-like strain A634 were confirmed to have SCP1 in an integrated form in the chromosome as originally shown by genetic analysis (Hopwood et al., 1985a), because no linear plasmid was detected by OFAGE, and pIJ601 hybridized to the origin of the gel containing the chromosomal DNA (Fig. $2 c, d$ ).

To study further the structure of integrated SCP1 in various $S$. coelicolor strains, we probed their DNA to seek the termini of SCP1 by Southern hybridization. Total DNAs from various strains were digested with BamHI and SpeI, separated by conventional agarose gel electrophoresis, and probed with pSCP201 containing the $4 \cdot 1 \mathrm{~kb}$ terminal SpeI fragment of SCP1 (Fig. 1). As shown in Fig. 6, M138, 1984, 2106 and JCM4979 displayed the $1.3 \mathrm{~kb}$ terminal $B a m H I$ fragment, indicating the presence of intact SCP1 termini. This was further supported by the presence of the $4 \cdot 1 \mathrm{~kb}$ terminal 

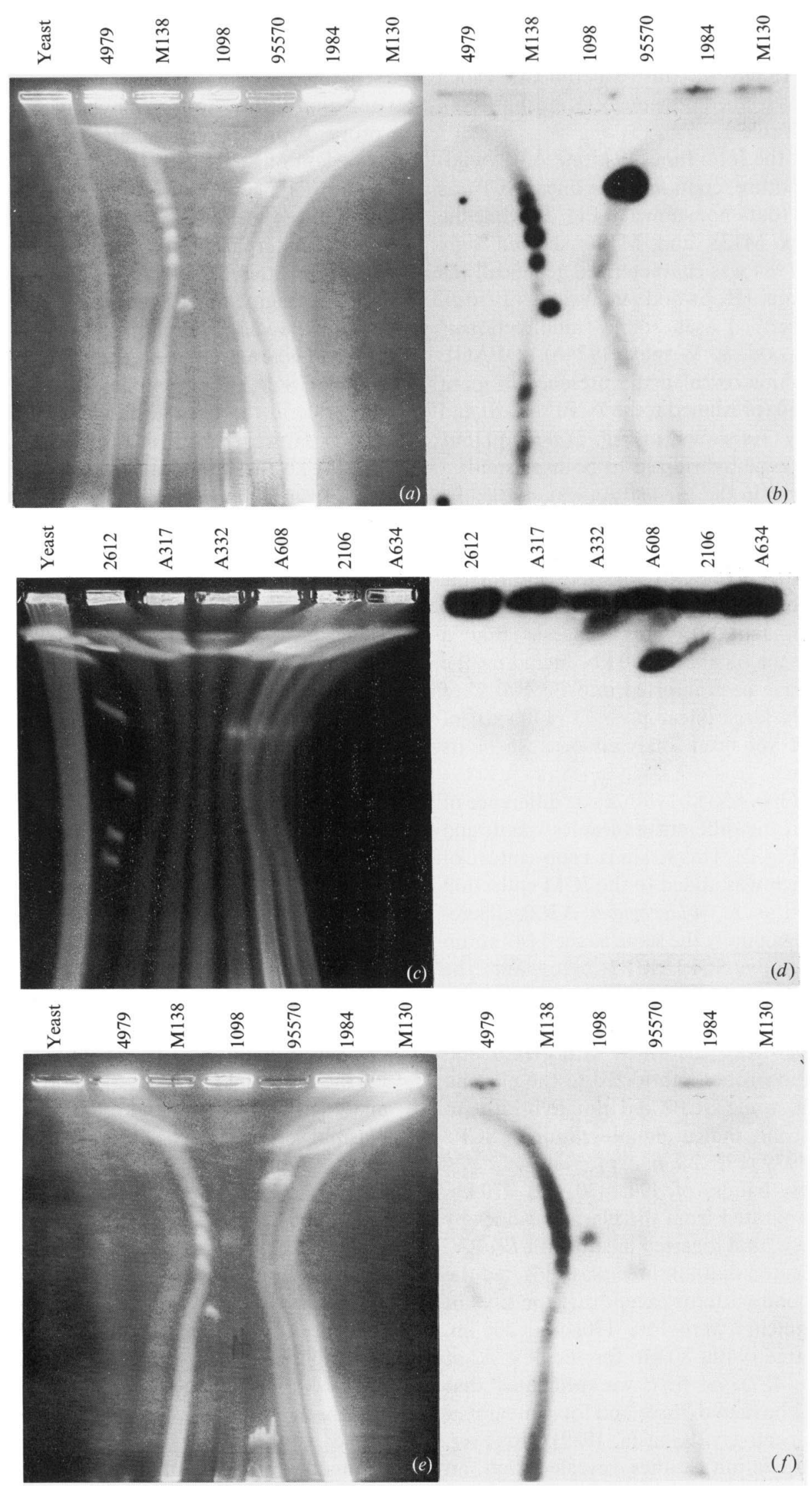
Table 1. Genetic and PFGE analyses of various S. coelicolor A3(2) and S. violaceoruber strains

\begin{tabular}{|c|c|c|c|c|}
\hline Strain & & PFGE analysis & Genetic analysis & Origin/Reference \\
\hline S. coelicolor A3(2) & $\begin{array}{l}1147 \\
\text { M138 } \\
\text { M146 } \\
1984 \\
2106 \\
2612 \\
\text { A317 } \\
\text { A332 } \\
\text { A608 } \\
\text { A634 } \\
1098 \\
\text { M124 } \\
\text { M130 } \\
\text { JCM4979 }\end{array}$ & $\begin{array}{l}\text { SCP1, } 350 \mathrm{~kb} \\
\mathrm{SCP} 1,350 \mathrm{~kb} \\
\mathrm{SCP} 1,350 \mathrm{~kb} \\
\mathrm{SCP1}-c y s B, 550 \mathrm{~kb} \\
\mathrm{SCP1} 1^{\prime}-c y s D, 1700 \mathrm{~kb} \\
\text { Integrated } \\
\text { Integrated } \\
\text { Integrated } \\
\text { Integrated } \\
\text { Integrated } \\
\text { SCP2, } 31 \mathrm{~kb} \text {, circular } \\
\quad- \\
\quad-\end{array}$ & 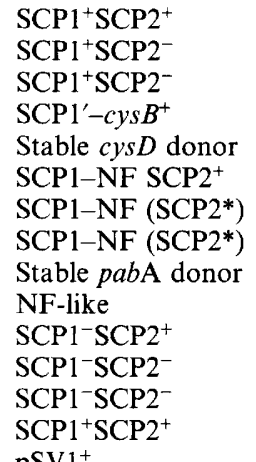 & $\begin{array}{l}\text { Hopwood (1959) } \\
\text { Bibb \& Hopwood (1981) } \\
\text { Bibb \& Hopwood (1981) } \\
\text { Hopwood \& Wright }(1976 a) \\
\text { Hopwood \& Wright }(1976 b) \\
\text { Lydiate et al. (1989) } \\
\text { Vivian \& Hopwood (1970) } \\
\text { Vivian \& Hopwood (1970) } \\
\text { Vivian \& Hopwood (1973) } \\
\text { Vivian \& Hopwood (1973) } \\
\text { Hopwood et al. (1969) } \\
\text { Bibb \& Hopwood (1981) } \\
\text { Bibb \& Hopwood (1981) } \\
\text { Hopwood (1959) }\end{array}$ \\
\hline S. violaceoruber & SANK 95570 & $\mathrm{pSV} 2,70 \mathrm{~kb}$ & $\mathrm{pSV}^{+}$ & Haneishi et al. (1974) \\
\hline
\end{tabular}

fragment in the SpeI digest of M138, 1984 and 2106. On the other hand, the three NF strains, 2612, A332, and A317, showed the same $1.7 \mathrm{~kb}$ Bam HI fragment containing the left junction (JL), which suggests that the structure of the integrated copy of SCP1 in A332 and A317 is identical to that in the 2612 strain (Hanafusa \& Kinashi, 1992). This result is consistent with the fact that the three strains are descendants of the same original NF strains (Vivian \& Hopwood, 1970). In contrast, A608 and A634 did not show any hybridizing band, indicating that at least the $4 \cdot 1 \mathrm{~kb}$ DNA was lost from both ends of SCP1 in these strains.

\section{pSV2, a large linear plasmid in S. violaceoruber SANK95570}

Okanishi et al. (1980) detected pSV1, a large circular plasmid, in $S$. violaceoruber SANK 95570 by electron microscopy. Aguilar \& Hopwood (1982) also detected probably the same plasmid by conventional agarose gel electrophoresis and implicated it in methylenomycin production by its hybridization to the $m m r$ probe. pSV1 is quite different from SCP1, in being a large circular plasmid of about $110 \mathrm{MDa}(170 \mathrm{~kb})$, based on microscopic observation and mobility in conventional gels.

We examined DNA of strain SANK 95570 by OFAGE and detected a large linear plasmid of $70 \mathrm{~kb}$ (Fig. $2 a, b$ ), which we named pSV2. However, pIJ601 hybridized to the origin of the gel, but not to the pSV2 band, showing that pSV2 does not carry the methylenomycin biosynthetic gene cluster.

\section{Analysis of the mmr fragment by Pst $\mathrm{I}$ digestion}

Chater \& Bruton (1985) studied the organization of the $m m y$ gene cluster by mutational cloning and showed the presence of two large transcription units of at least $6.6 \mathrm{~kb}$ and $9.5 \mathrm{~kb}$. These transcripts include at least four biosynthetic genes and one resistance gene for methylenomycin. They also showed that the restriction patterns for this region of SCP1 and $\mathrm{pSV} 1$ are similar but not identical. To examine the organization of this region in various strains, we analysed Pst I fragments of total DNAs of the $S$. coelicolor and S. violaceoruber strains listed in Table 1 using pIJ601 as a probe. All the methylenomycin-producing strains except for $S$. violaceoruber SANK 95570 gave the same $2.6 \mathrm{~kb} \mathrm{mmr}$ fragment regardless of their SCP1 states (Fig. 7). This result suggests that the $m m r$ region, at least, did not rearrange during integration, excision or amplification even in the plasmid ladder in strain JCM4979. Pst I digestion of total DNA of $S$. violaceoruber SANK95570 gave a $5.5 \mathrm{~kb}$ fragment, which agrees with Chater \& Bruton (1985).

\section{Discussion}

In this paper, we confirmed that SCP1 exists in $S$. coelicolor A3(2) strains in three forms which had been previously suggested by Hopwood and his colleagues by genetic analysis; namely the giant linear plasmid SCP1 in the SCP1 ${ }^{+}$S. coelicolor strains 1147, M138 and M146, the SCP1' plasmids containing an extra DNA fragment in S. coelicolor 1984 and 2106, and the integrated state in

Fig. 2. OFAGE $(a, c, e)$ and Southern blot $(b, d, f)$ analyses of various $S$. coelicolor strains. OFAGE was done with $1 \%(\mathrm{w} / \mathrm{v})$ agarose in $0.5 \times \mathrm{TBE}$ at $300 \mathrm{~V}$, with switching interval of $30 \mathrm{~s}(a, b, e, f)$ or $20 \mathrm{~s}(c, d)$ and a total time of $24 \mathrm{~h}$. S. cerevisiae YNN27 chromosomes were used as size markers. The sizes of SCP1'-cysB (in strain 1984) and the SCP1' plasmid of strain 2106 were confirmed using longer pulse times. ${ }^{32} \mathrm{P}$-labelled pIJ601 $(b, d)$ and ${ }^{32} \mathrm{P}$-labelled SCP2 $(f)$ were used as probes for Southern hybridization. 

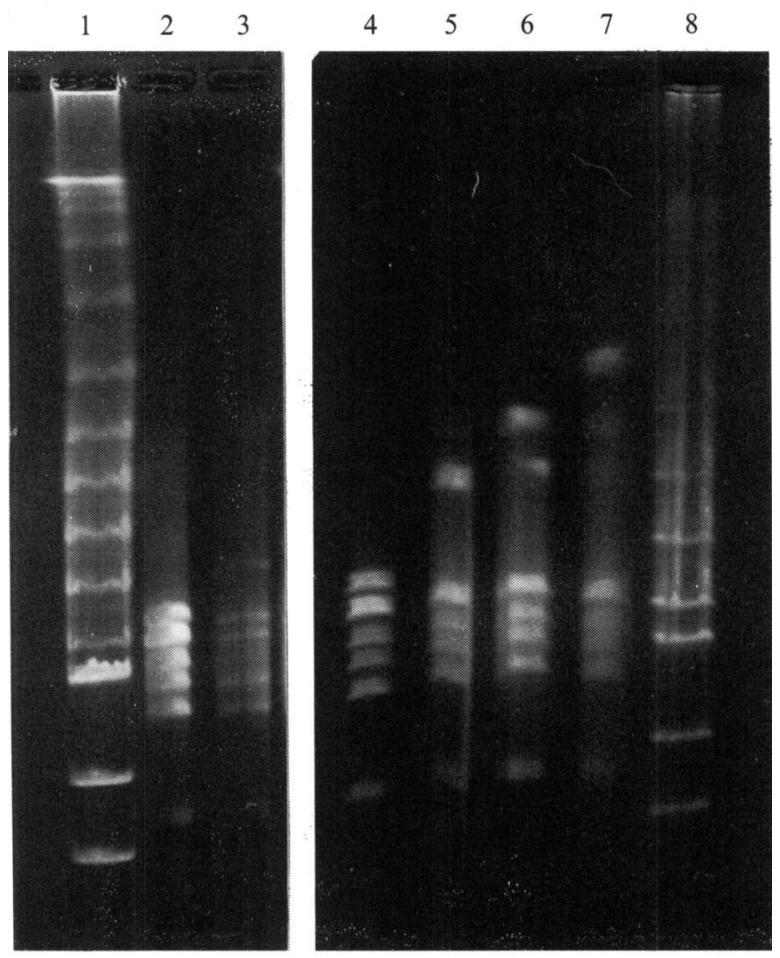

Fig. 3. CHEF analysis of the $E c o$ RV digests of $S C P 1^{\prime}-c y s B$ from strain 1984 and the plasmid ladder from strain JCM4979. Lanes: 1, 8, $\lambda$ DNA concatemer $+\lambda$ DNA digested with HindIII; 2, 4, SCP1 digested with $E c o \mathrm{RV} ; 3, \mathrm{SCP} 1^{\prime}-c y s B$ digested with $E c o \mathrm{RV} ; 5-7$, three plasmids from the plasmid ladder of strain 4979 digested with $E c o$ RV. In the $\mathrm{SCP} 1^{\prime}-c y s B$ digest, only the EcoRV-C fragment of SCP1 $(40 \mathrm{~kb})$ changed to $E c o \mathrm{RV}-\mathrm{C}^{\prime}(140 \mathrm{~kb})$. In the digests of the plasmid ladder, only the EcoRV-A fragment of SCP1 $(80 \mathrm{~kb})$ changed to $E c o \mathrm{RV}-\mathrm{A}^{\prime}$ $(150,190$ and $230 \mathrm{~kb})$. CHEF was conducted with $1 \%$ (w/v) agarose gel in $0.5 \times$ TBE at $180 \mathrm{~V}$, with switching interval of $30 \mathrm{~s}$ and a total time of $24 \mathrm{~h}$.

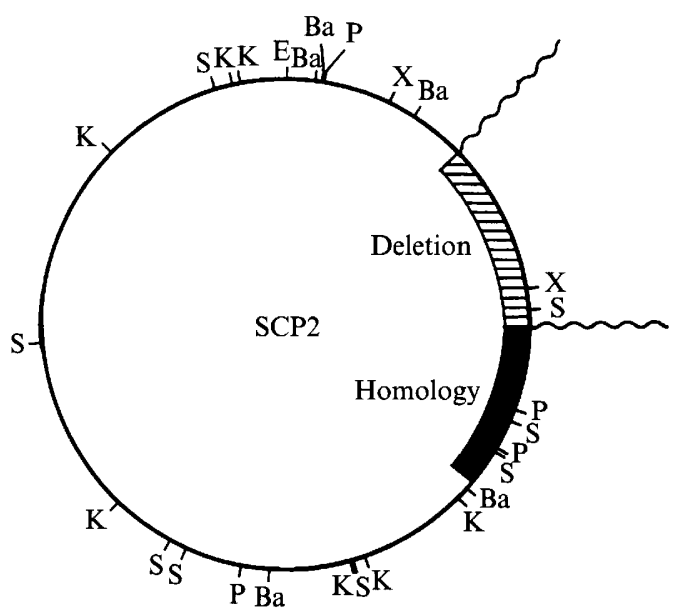

Fig. 4. The structure of SCP2 in the plasmid ladder of JCM4979. The physical map of SCP2* is reproduced from Lydiate et al. (1985). The shaded and black regions indicate the deleted sequence in the plasmid ladder ( $4.0-8.0 \mathrm{~kb}$ from the $E c o \mathrm{RI}$ site) and the homologous sequence to SCP1 (8.0-11.5 kb from the EcoRI site), respectively. Part of the SCP1 sequence is indicated by waved lines. Ba, BamHI; E, EcoRI; K, KpnI ; P, PstI; S, SphI; X, XbaI.

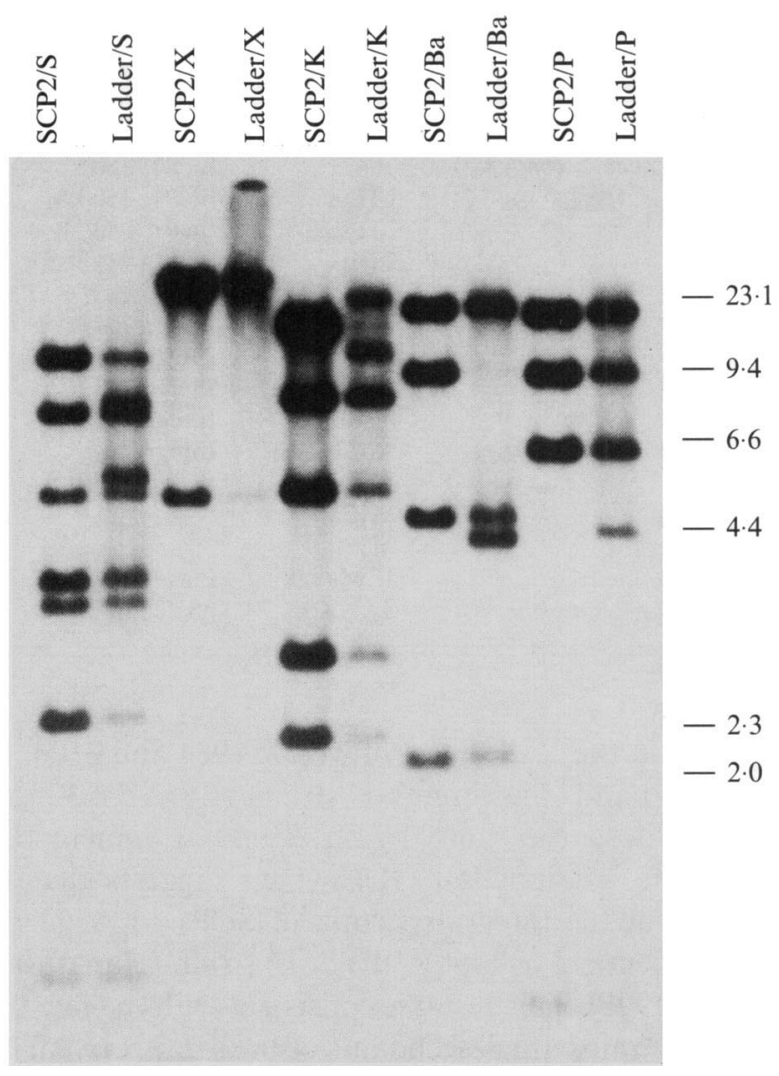

Fig. 5. Southern blot analysis of the integrated copy of SCP2 in the plasmid ladder from strain JCM4979. SCP2 and the DNA from the plasmid ladder were digested with five restriction endonucleases, separated by conventional gel electrophoresis, and probed with ${ }^{32} \mathrm{P}$ labelled SCP2. The $5.0 \mathrm{~kb} \mathrm{XbaI,} 13.2 \mathrm{~kb} \mathrm{KpnI}$ and $8.9 \mathrm{~kb}$ BamHI fragments of SCP2 were not observed on the plasmid DNA digest, suggesting that the upper right region on the circular SCP2 map is absent from the plasmid ladder (Fig. 4). S, SphI; X, XbaI; K, KpnI; Ba, BamHI; P, PstI. Numbers on the right side indicate the positions of the HindIII fragments of $\lambda$ DNA.

the three NF strains 2612, A317, A332 and in the strains A608 and A634. A series of SCP1-related plasmids were also found in S. coelicolor JCM4979.

The structures of integrated SCP1 copies in various strains were studied by hybridization using pSCP201 as a probe. The NF strains 2612, A317 and A332 gave the same $1.7 \mathrm{~kb}$ Bam HI fragment containing JL (Hanafusa \& Kinashi, 1992), which suggests an identical integrated structure of SCP1 in these NF strains. S. coelicolor A608 and A634 did not show any hybridizing bands, however, indicating that both ends of SCP1 were deleted at least $4.1 \mathrm{~kb}$ from the terminus. We previously proposed a model for the origin of the NF strain based on structural analysis of SCP1 in the 2612 strain (Hanafusa \& Kinashi, 1992; Kinashi et al., 1992). This integration model for SCP1 could also be applied to S. coelicolor A608 and A634. Thus, SCP1 might be integrated into the chromosome at the 9 o'clock position following the racket-frame model (Sakaguchi, 1990), and deletions of a different 

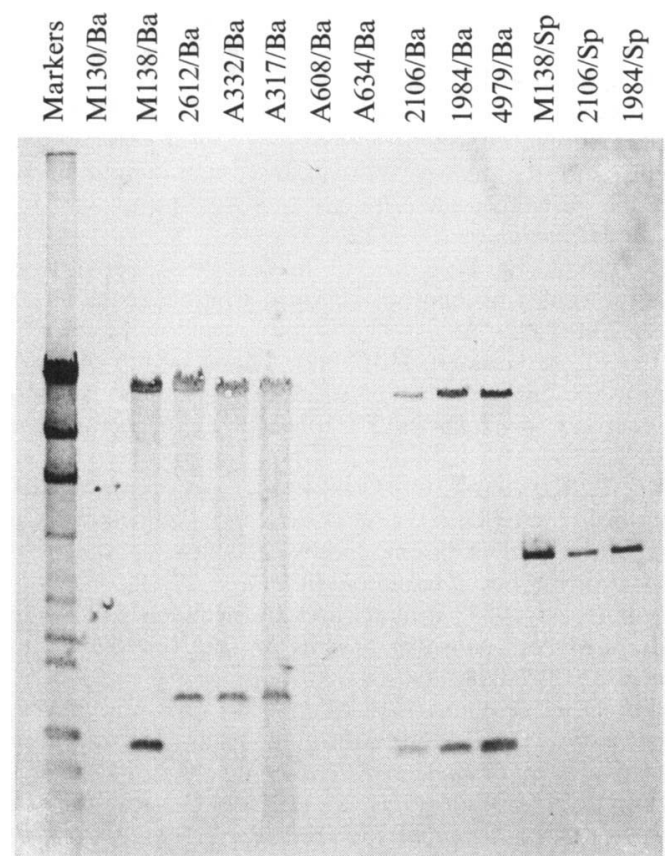

Fig. 6. Southern blot analysis of the terminus of SCP1 in various $S$. coelicolor strains. Total DNAs were digested with BamHI and SpeI, respectively, separated by conventional gel electrophoresis and probed by pSCP201, $\lambda$ DNA and $\phi \times 174$ DNA labelled with digoxigeninlabelled dUTP. $\lambda$ DNA digested with HindIII and $\phi \times 174$ DNA digested with $\mathrm{HaeIII}$ were used as size markers. The $\mathrm{SCP} 1^{+} \mathrm{M} 138$ strain was used as a control. The 2106,1984 and JCM4979 strains were revealed to contain the intact terminus of SCP1. The SCP1-NF strains 2612, A317 and A332 gave the $1.7 \mathrm{~kb}$ JL fragment. The A608 and A634 strains, carrying the integrated SCP1 plasmid, had no hybridizing bands. type from 2612 might subsequently occur at both ends of SCP1 to form the A608 and 634 strains.

A unique feature of NF strains is that they donate chromosomal markers bidirectionally at high frequency during conjugal mating, unlike $\mathrm{Hfr}$ strains of $E$. coli, which donate unidirectionally. The A608 and A634 strains were reported to show unidirectional and bidirectional gene transfers, respectively (Vivian \& Hopwood, 1973), which suggests that the terminus itself may not be important in determining the direction of gene transfer. The molecular reason for bi- and unidirectional gene transfers may reflect the direction of insertion and extent of deletion of SCP1 in various strains.

The two SCPl' plasmids from S. coelicolor 1984 and 2106 have the intact termini of SCP1. Preliminary physical mapping of plasmid $\mathrm{SCP}^{\prime}-c y s B(550 \mathrm{~kb})$ indicated that the $c y s B$ gene is located on the $E c o \mathrm{RV}-\mathrm{C}^{\prime}$ fragment. Therefore, the formation mechanism of these SCP1' plasmids may be more complicated than a simple excision of an integrated SCP1 from the chromosome together with an adjacent chromosomal DNA fragment such as $c y s B$.

A series of SCP1-related plasmids in S. coelicolor JCM4979 were revealed to have the same restriction map as SCP1 except for the size of the EcoRV-A' fragment. Our data indicate that the integrated SCP2 in the plasmid ladder is not intact but has a $4.0 \mathrm{~kb}$ deletion on the upper right of the SCP2 map. Therefore, the series of plasmids in strain JCM4979 were not the result of integration of different numbers of SCP2 molecules into

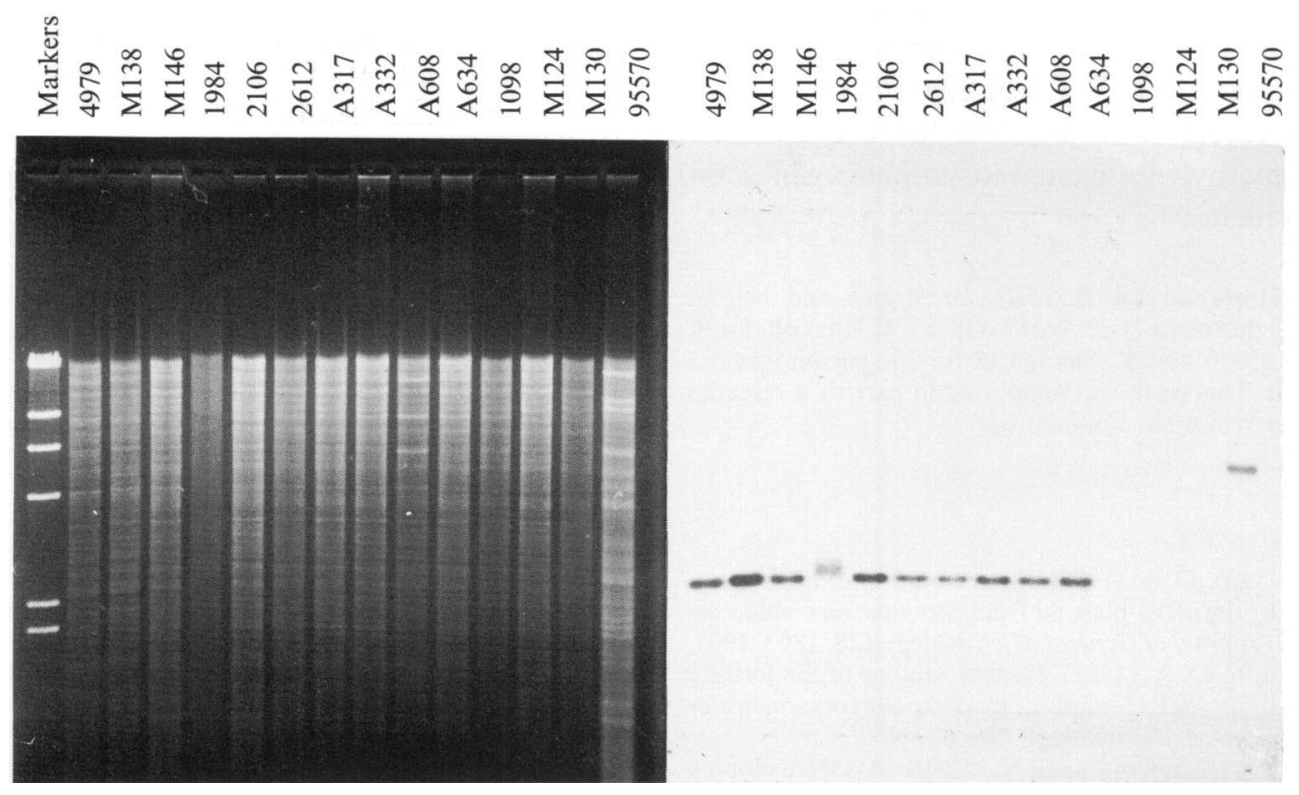

Fig. 7. Analysis of the $m m r$ gene structure in various $S$. coelicolor strains. Total DNAs from various strains were digested with $P$ stI, separated by conventional gel electrophoresis and probed with ${ }^{32} \mathrm{P}$-labelled pIJ601. All the methylenomycin producers gave the same $2.6 \mathrm{~kb}$ fragment, except the SANK 95570 strain, which gave a $5.5 \mathrm{~kb}$ fragment. 
SCP1, but might have been formed by amplification of the adjacent SCP1 region of the EcoRV-A' fragment. We recently found a homologous DNA sequence between SCP1 and SCP 2 which is about $3.5 \mathrm{~kb}$ long. This sequence is present from $8.0 \mathrm{~kb}$ to $11.5 \mathrm{~kb}$ from the EcoRI site of SCP2 (Fig. 4) and its centre is about $5.0 \mathrm{~kb}$ from the inside end of TIR-L of SCP1 (Fig. 1) (data not shown). Therefore, integration of one molecule of SCP2 into SCP1 by homologous recombination between these sequences followed by deletion and amplification in the $E c o \mathrm{RV}-\mathrm{A}^{\prime}$ fragment might have formed a series of plasmids in the JCM4979 strain.

Many cases of site-specific integration or excision of a circular plasmid into or from the chromosomal DNA have been described in actinomycetes (Omer \& Cohen, 1986; Huetter et al., 1988). To our knowledge, however, the plasmid ladder in JCM4979 is the first example in which a circular plasmid is integrated into a giant linear plasmid. It is also noteworthy that deletion and amplification have occurred adjacently on the EcoRV-A' fragment of the plasmid ladder. In Streptomyces chromosomal DNA, amplification frequently occurs adjacent to deletion, as with $\arg G$ mutants of Streptomyces lividans 66 (Schrempf et al., 1988).

We further detected a large linear plasmid, pSV2, in $S$. violaceoruber SANK95570, but this plasmid was shown by hybridization not to carry the methylenomycin gene cluster. A large circular plasmid pSV1 has been detected in the same strain, and is reportedly involved in methylenomycin production. If the $m m y$ gene cluster is located on three different genomes, namely the giant linear plasmid SCP1, the circular plasmid pSV1, and the chromosome, it is an extraordinary phenomenon that has never been observed before. However, the properties of pSV1 are not yet clear. Physical characterization of pSV1 may also reveal some reasons for the dynamic transfer of the methylenomycin biosynthetic genes on various DNA vehicles.

We thank D. A. Hopwood for S. coelicolor strains and helpful suggestions regarding the manuscript. We also thank T. Haneishi for $S$. violaceoruber SANK 95570 and K. Sakaguchi for his encouragement throughout this work. This work was supported in part by a research grant from the Japan Waksman Foundation.

\section{References}

Aguilar, A. \& Hopwood, D. A. (1982). Determination of methylenomycin A synthesis by the $\mathrm{pSV1}$ plasmid from Streptomyces violaceusruber SANK95570. Journal of General Microbiology 128, 1893-1901.

BiBb, M. J. \& Hopwood, D. A. (1981). Genetic studies of the fertility plasmid SCP2 and its SCP2* variant in Streptomyces coelicolor A3(2). Journal of General Microbiology 126, 427-442.

BibB, M., SchotTel, J. L. \& Cohen, S. N. (1980). A DNA cloning system for interspecies gene transfer in antibiotic-producing Streptomyces. Nature, London 284, 526-531.

CARLE, G. F. \& OLSON, M. V. (1987). Orthogonal-field-alternation gel electrophoresis. Methods in Enzymology 155, 468-482.
ChATER, K. F. \& Bruton, C. J. (1985). Resistance, regulatory and production genes for the antibiotic methylenomycin are clustered. EMBO Journal 4, 1893-1897.

Chater, K. F., Henderson, D. J., BibB, M. J. \& Hopwood, D. A. (1988). Genome flux in Streptomyces coelicolor and other streptomycetes and its possible relevance to the evolution of mobile antibiotic resistance determinants. Symposia of the Society for General Microbiology 43, 7-42.

Chu, G., Vollrath, D. \& Davis, R. W. (1986). Separation of large DNA molecules by contour-clamped homogeneous electric fields. Science 234, 1582-1585.

Hanafusa, T. \& Kinashi, H. (1992). The structure of an integrated copy of the giant linear plasmid SCP1 in the chromosome of Streptomyces coelicolor 2612. Molecular and General Genetics 231, 363-368.

Haneishi, T., Kitahara, N., Takiguchi, Y. \& Arai, M. (1974). New antibiotics, methylenomycins A and B. I. Producing organism, fermentation and isolation, biological activities and physical and chemical properties. Journal of Antibiotics 27, 386-392.

HoPwOOD, D. A. (1959). Linkage and the mechanism of recombination in Streptomyces coelicolor. Annals of the New York Academy of Sciences 81, 887-898.

Hopwood, D. A. \& WRIGHT, H. M. (1973). A plasmid of Streptomyces coelicolor carrying a chromosomal locus and its inter-specific transfer. Journal of General Microbiology 79, 331-342.

HopwOOD, D. A. \& WRIGHT, H. M. (1976a). Genetic studies on SCP1prime strains of Streptomyces coelicolor A3(2). Journal of General Microbiology 95, 107-120.

HOPWOOD, D. A. \& WRIGHT, H. M. (1976b). Interaction of the plasmid SCP1 with the chromosome of Streptomyces coelicolor A3(2). In Second International Symposium on the Genetics of Industrial Microorganisms, pp. 607-619. Edited by K. D. MacDonald. London: Academic Press.

Hopwood, D. A., Harold, R. J., Vivian, A. \& Ferguson, H. M. (1969). A new kind of fertility variant in Streptomyces coelicolor. Genetics 62, 461-477.

Hopwood, D. A., Chater, K. F., Dowding, J. E. \& Vivian, A. (1973). Advances in Streptomyces coelicolor genetics. Bacteriological Reviews 37, 371-405.

Hopwood, D. A., Lydiate, D. J., Malpartida, F. \& Wright, H. M. (1985a). Conjugative sex plasmids of Streptomyces. In Plasmids in Bacteria, pp. 615-633. Edited by D. R. Helinski, S. N. Cohen, D. B. Clewell, D. A. Jackson \& A. Hollaender. New York \& London: Plenum Press.

Hopwood, D. A., Bibb, M. J., Chater, K. F., Kieser, T., Bruton, C. J., Kieser, H. M., Lydiate, D. J., Smith, C. M., WARD, J. M. \& SCHREMPF, H. (1985b). Genetic Manipulation of Streptomyces, a Laboratory Manual, p. 257. Norwich: John Innes Foundation.

Huetter, R., Birch, A., Haeusler, A., Voegtli, M., Madon, J. \& KrEK, W. (1988). Genome fluidity in Streptomyces. In Biology of Actinomycetes' 88 , pp. 111-116. Edited by Y. Okami, T. Beppu \& H. Ogawara. Tokyo: Japan Scientific Societies Press.

Kendall, K. \& Cullum, J. (1986). Identification of a DNA sequence associated with plasmid integration in Streptomyces coelicolor A3(2). Molecular and General Genetics 202, 240-245.

KINASHI, H. (1989). Giant linear plasmids in various methylenomycinproducing strains of Streptomyces species. In Genetics and Molecular Biology of Industrial Microorganisms, pp. 141-146. Edited by C. L. Hershberger, S. W. Queener \& G. Hegeman. Washington, DC: American Society for Microbiology.

Kinashi, H. \& Shimaji-Murayama, M. (1991). Physical characterization of SCP1, a giant linear plasmid from Streptomyces coelicolor. Journal of Bacteriology 173, 1523-1529.

KINASHI, H., ShimaJi, M. \& SAKaI, A. (1987). Giant linear plasmids in Streptomyces which code for antibiotic biosynthesis genes. Nature, London 328, 454-456.

Kinashi, H., Shimaji-Murayama, M. \& Hanafusa, T. (1991). Nucleotide sequence analysis of the unusually long terminal inverted repeats of a giant linear plasmid, SCP1. Plasmid 26, 123-130.

Kinashi, H., Shimaji-Murayama, M. \& Hanafusa, T. (1992). Integration of SCP1, a giant linear plasmid, into the Streptomyces coelicolor chromosome. Gene 115, 35-41. 
KiRBY, R. \& Hopwood, D. A. (1977). Genetic determination of methylenomycin synthesis by the SCP1 plasmid of Streptomyces coelicolor A3(2). Journal of General Microbiology 98, 239-252.

Kirby, R., Wright, L. F. \& Hopwood, D. A. (1975). Plasmiddetermined antibiotic synthesis and resistance in Streptomyces coelicolor. Nature, London 254, 265-267.

Lydiate, D. J., Malpartida, F. \& Hopwood, D. A. (1985). The Streptomyces plasmid SCP2*: its functional analysis and development into useful cloning vectors. Gene 35, 223-235.

Lydiate, D. J., Ashby, A. M., Henderson, D. J., Kieser, H. M. \& Hopwood, D. A. (1989). Physical and genetic characterization of chromosomal copies of the Streptomyces coelicolor mini-circle. Journal of General Microbiology 135, 941-955.

McCormick, J. R., Santamaria, R. \& Losick, R. (1991). The genes for three spore-associated proteins are encoded on linear plasmid SCP1 in Streptomyces coelicolor. Proceedings of the 8th International Symposium on Biology of Actinomycetes, Madison, Wisconsin, p. 125.

OKanishi, M., Manome, T. \& Umezawa, H. (1980). Isolation and characterization of plasmid DNAs in actinomycetes. Journal of Antibiotics 33, 88-91.

OMER, C. A. \& COHEN, S. N. (1986). Structural analysis of plasmid and chromosomal loci involved in site-specific excision and integration of the SLP1 element of Streptomyces coelicolor. Journal of Bacteriology 166, 999-1006.
SAKAGUCHI, K. (1990). Invertrons, a class of structurally and functionally related genetic elements that includes linear DNA plasmids, transposable elements, and genomes of adeno-type viruses. Microbiological Reviews 54, 66-74.

SambrooK, J., Fritsch, E. F. \& Maniatis, T. (1989). Molecular Cloning, a Laboratory Manual, 2nd edn. Cold Spring Harbor, NY: Cold Spring Harbor Laboratory Press.

SchrempF, H., Dyson, P., Dittrich, W., Betzler, M., Habiger, C. Mahro, B., Bronneke, V., Kessler, A. \& Duvel, H. (1988). Genetic instability in Streptomyces. In Biology of Actinomycetes ' $88, \mathrm{pp}$. 145-150. Edited by Y. Okami, T. Beppu \& H. Ogawara. Tokyo: Japan Scientific Societies Press.

Tanaka, T., Kuroda, M. \& SaKaguchi, K. (1977). Isolation and characterization of four plasmids from Bacillus subtilis. Journal of Bacteriology 129, 1487-1494.

VIVIAN, A. (1971). Genetic control of fertility in Streptomyces coelicolor A3(2): Plasmid involvement in the interconversion of UF and IF strains. Journal of General Microbiology 69, 353-364.

VIVIAN, A. \& HopwOOD, D. A. (1970). Genetic control of fertility in Streptomyces coelicolor A3(2): the IF fertility type. Journal of General Microbiology 64, 101-117.

Vivian, A. \& HopwOOD, D. A. (1973). Genetic control of fertility in Streptomyces coelicolor A3(2): new kinds of donor strains. Journal of General Microbiology 76, 147-162. 